\title{
Ab initio structure determination of two new titanium phosphates synthesized via molten salt synthesis.
}

\author{
H. Petersen ${ }^{1}$, N. Stegmann ${ }^{1}$, M. Fischer ${ }^{2,3}$, B. Zibrowius ${ }^{1}$, W. Schmidt ${ }^{1}$, M. Etter ${ }^{4}$, C. Weidenthaler ${ }^{1}$ \\ ${ }^{1}$ Max-Planck-Institut für Kohlenforschung, Heterogeneous Catalysis, Kaiser-Wilhelm-Platz 145470 Mülheim, Germany, \\ ${ }^{2}$ Crystallography/Geosciences, University of Bremen, Klagenfurter Straße 28359 Bremen, Germany, \\ ${ }^{3}$ MAPEX Center for Materials and Processes, University of Bremen, 28334 Bremen, Germany, \\ ${ }^{4}$ Deutsches Elektronen-Synchrotron (DESY), Notkestraße 8522607 Hamburg, Germany
}

petersen@kofo.mpg.de

The class of transition metal phosphates (TMPs) shows a wide range of chemical compositions, variations of valence states and respective crystal structures. Among TMPs, $\mathrm{VO}\left(\mathrm{P}_{2} \mathrm{O}_{7}\right)$ and $\mathrm{LiFePO}_{4}$ are of special interest as the only commercially used heterogeneous catalyst for the selective oxidation of butane to maleic anhydride [1] and cathode material in rechargeable batteries [2]. Due to their structural features, TMPs are considered as proton exchange-membranes in fuel cells, working in the intermediatetemperature range $[2,3]$. We report on the successful ab initio structure determination of two novel titanium pyrophosphates, $\mathrm{NH}_{4} \mathrm{Ti}(\mathrm{III}) \mathrm{P}_{2} \mathrm{O}_{7}$ and $\mathrm{Ti}(\mathrm{IV}) \mathrm{P}_{2} \mathrm{O}_{7}$, from X-ray powder diffraction data. Both compounds were synthesized via a new molten salt synthesis route. The low symmetry space groups $\mathrm{P} 2_{1} / \mathrm{c}\left(\mathrm{NH}_{4} \mathrm{TiP}_{2} \mathrm{O}_{7}\right)$ and $\mathrm{P}-1\left(\mathrm{TiP}_{2} \mathrm{O}_{7}\right)$ complicate the structure determination, making

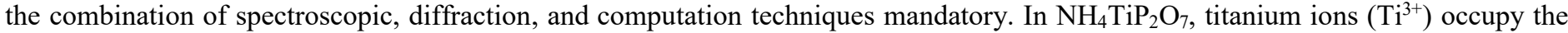
$\mathrm{TiO}_{6}$ polyhedron, coordinated by five pyrophosphate groups, one as a bi-dentate ligand. This secondary coordination causes the formation of one-dimensional six-membered ring channels with a diameter $d_{\max }$ of 514(2) pm, stabilized by ammonium ions. Annealing $\mathrm{NH}_{4} \mathrm{TiP}_{2} \mathrm{O}_{7}$ in inert atmospheres results in the formation of the new $\mathrm{TiP}_{2} \mathrm{O}_{7}$, showing a similar framework consisting of $\left[\mathrm{P}_{2} \mathrm{O}_{7}\right]^{4-}$ units and $\mathrm{TiO}_{6}$ octahedra as well as an empty one-dimensional channel $\left(\mathrm{d}_{\max }=628(1) \mathrm{pm}\right)$. The structures can be related to the high-voltage pyrophosphate cathode material $\mathrm{Li}_{2} \mathrm{FeP}_{2} \mathrm{O}_{7}$ also crystallizing in $\mathrm{P}{ }_{1} / \mathrm{c}$ [4]. $\mathrm{Li}_{2} \mathrm{FeP}_{2} \mathrm{O}_{7}$ consists of a three-dimensional arrangement of undulating $\left[\mathrm{Fe}_{4} \mathrm{P}_{8} \mathrm{O}_{32}\right]_{\infty}$ layers [4] building a channel system that is occupied by $\mathrm{Li}^{+}$ions. The structural relation to $\mathrm{Li}_{2} \mathrm{FeP}_{2} \mathrm{O}_{7}$ implies a good proton conductivity of $\mathrm{NH}_{4} \mathrm{Ti}(\mathrm{III}) \mathrm{P}_{2} \mathrm{O}_{7}$ and $\mathrm{Ti}(\mathrm{IV}) \mathrm{P}_{2} \mathrm{O}_{7}$. Both newly synthesized phosphates, $\mathrm{NH}_{4} \mathrm{Ti}(\mathrm{III}) \mathrm{P}_{2} \mathrm{O}_{7}$ and $\mathrm{Ti}(\mathrm{IV}) \mathrm{P}_{2} \mathrm{O}_{7}$, show a proton conductivity based on the Grotthus mechanism. The activation energy of the proton migration of $\mathrm{NH}_{4} \mathrm{Ti}(\mathrm{III}) \mathrm{P}_{2} \mathrm{O}_{7}$ belongs to the lowest which has been reported for this class of materials and indicates its potential application as a proton electrolyte in the intermediate temperature range. In situ X-ray diffraction study of the transformation of $\mathrm{NH}_{4} \mathrm{TiP}_{2} \mathrm{O}_{7}$ to $\mathrm{TiP}_{2} \mathrm{O}_{7}$ reveals a two-step mechanism, the decomposition of ammonium ions coupled with the oxidation of $\mathrm{Ti}^{3+}$ to $\mathrm{Ti}^{4+}$ and subsequent structural relaxation.

[1] Hutchings, G.J. (2004). J. Mater. Chem., 14, 3385.

[2] Jin, Y., Y. Shen, and T. Hibino (2010). J. Mater. Chem., 206214.

[3] Nalini, V., M.H. Sørby, K. Amezawa, R. Haugsrud, H. Fjellvåg, and T. Norby (2011). J. Am. Ceram. Soc., 941514.

[4] Clark, J.M., S.-i. Nishimura, A. Yamada, and M.S. Islam, (2012). Angew. Chem. Int. Ed., 2012. 5113149.

Keywords: structure determination, transition metal phosphates, proton conductivity, in-situ investigation

We acknowledge DESY (Hamburg, Germany) a member of the Helmholtz Association HGF, for the provision of experimental facilities. Parts of this research were carried out at PETRA III, beamline P02.1. We thank ZBT (Duisburg, Germany) for the possibility of Protonconductivity measurements. 